Environmental Research Journal 6(3): 197-205, 2012

ISSN: 1994-5396

(C) Medwell Journals, 2012

\title{
Assessment of Irrigation Potential of Groundwater using Water Quality Index Tool
}

\author{
K. Adhikari, B. Chakraborty and A. Gangopadhyay \\ Department of Geology, National Institute of Technology, \\ 713209 Durgapur, West Bengal, India
}

\begin{abstract}
Transforming parametric concentrations into qualitative scores irrespective of unit has made the WQI a comprehensive and easy to use tool to the decision makers. As criteria of water quality vary with purpose of use of the groundwater, selection of water quality parameters, involved in working out quality index for specific use also differs. Use of Groundwater Quality Index (GWQI) technique to assess irrigation water quality is innovative in this study. Electrical Conductivity (EC), Sodium Adsorption Ratio (SAR) and Residual Sodium Carbonate (RSC), judged as the three most important parameters to designate irrigation quality of groundwater have been used to work out GWQI in this study. Preparation of ISO Index maps using water quality scores, derived through GWQI tool, vividly portray the irrigation water quality status of the study area where most of the area fall under excellent and good categories. The marked difference in water quality with respect to season in some areas of Southeastern and Southwestern parts of the study area may be correlatable to the recharge and discharge zones of groundwater, respectively.
\end{abstract}

Key words: Water quality parameters, Groundwater Quality Index (GWQI), ISO Index maps, recharge zone, discharge zone, India

\section{INTRODUCTION}

In most of the important agriculture production areas, groundwater becomes the sole source of freshwater when surface water sources have been depleted. In many concentrations of intensive agriculture, groundwater offers reliability and flexibility in access to water that irrigation canals can hardly match. Worldwide, total groundwater withdrawals are estimated to be in the range $600-1100 \mathrm{~km}^{3} /$ year or between one fifth and one third of the total global freshwater withdrawals (Doll, 2009; Shah et al., 2007; Zekster and Everett, 2004). Aquifer depletion has been reported for many semiarid and arid regions worldwide and can be attributed to agricultural usage (Ahmed and Umar, 2009; Central Ground Water Board, 2006; Foster and Loucks, 2006; Guzman-Soria et al., 2009; Scanlon et al., 2007; Shah et al., 2007; Wang et al., 2009).

Globally irrigation accounts for $>70 \%$ of total water withdrawals and for $>90 \%$ of total consumptive water use (Doll, 2009; FAO, 201 0; Shiklomanov, 2000). Groundwater sustains almost $60 \%$ of the irrigated land in India (MoA-GoI, 2003). On a local level, an increasing number of districts use groundwater for irrigation purpose than surface water. Here, during 1960-99 period, irrigation from tube wells and other wells grew $>4$ times and currently represents well over half of the countries irrigated area
(Scott and Sharma, 2009). In just two decades, the groundwater irrigated lands in India have increased by 105\% (IWMI, 2005). Quality aspect of groundwater determines the suitability of its use in agriculture. Quality of groundwater varies with space in its natural hydrogeological setting but changes of quality of groundwater with time in a particular space are often attributed to anthropogenic reasons. So, to evaluate the irrigation potential of a region groundwater quality characterization reflecting through, a suitable representative classification scheme in a time perspective is a must. The present study has made an attempt in this regard. The objectives of the present study are:

- To evaluate water quality parameters with respect to irrigation potential

- To classify groundwater of the study area, depending upon the combinations of water quality parameters with respect to suitability for irrigation

Electrical Conductivity (EC), relative proportion of sodium to other cations, residual sodium carbonate, etc. are important parameters, judged for quality of irrigation water (Ragunath, 2006). Considering an individual parameter for classification of water is not sufficient for all the samples of the area as it cannot properly explain which parameter should be given higher weightage or

Corresponding Author: B. Chakraborty, Department of Geology, National Institute of Technology, 713209 Durgapur, West Bengal, India 
importance. Classification based on individual parameter often creates confusion to designate different locations with respect to irrigation quality of groundwater of an area. Better results can be obtained by considering the combined chemistry of the parameters rather than individual one (Handa, 1964, 1965; Hem, 1985; Karmegam et al., 2010). So, to determine the irrigation water quality consisting of a number of samples in a region, a proper indexing system involving electrical conductivity, Sodium Adsorption Ratio (SAR) and residual sodium carbonate is proposed.

The study area comprises of complex nature of landuse pattern. The area is characterized by industries, agriculture, forest, urban and rural residential hubs. In recent years, a number of large, medium and small industries of different nature (like cement industries, alloy industries, polymer industries, etc.) have been set up in this area. Coal bed methane exploration and exploitation is going on in the North Eastern and North Western part of the study area for the last few years. The effluents of these industries of various natures stay around the agricultural lands and may have control on the quality of groundwater which is used for agriculture.

Study area: The area under investigation belongs to the survey of India toposheet No. 73M/6 and 73M/7 (1:50,000 scale) lying between latitudes $23^{\circ} 25^{\prime}$ and $23^{\circ} 48^{\prime} \mathrm{N}$ and longitudes $87^{\circ} 10^{\prime}$ and $87^{\circ} 35^{\prime} \mathrm{E}$, covering an area of almost $600 \mathrm{~km}^{2}$ (Fig. 1). The River Ajoy forms the Northern boundary and River Damodar maps the Southern boundary. Northern and Western part of the study area consists of coal bearing Raniganj Formation of Gondwana Supergroup which is overlain by alluvium (Central Ground Water Board, 2006). The Eastern and Southeastern part is constituted by alluvium blanket comprising of alluvium, laterite, sand, gravel and clay, etc. of Upper TertiaryQuaternary age (Central Ground Water Board, 2006).

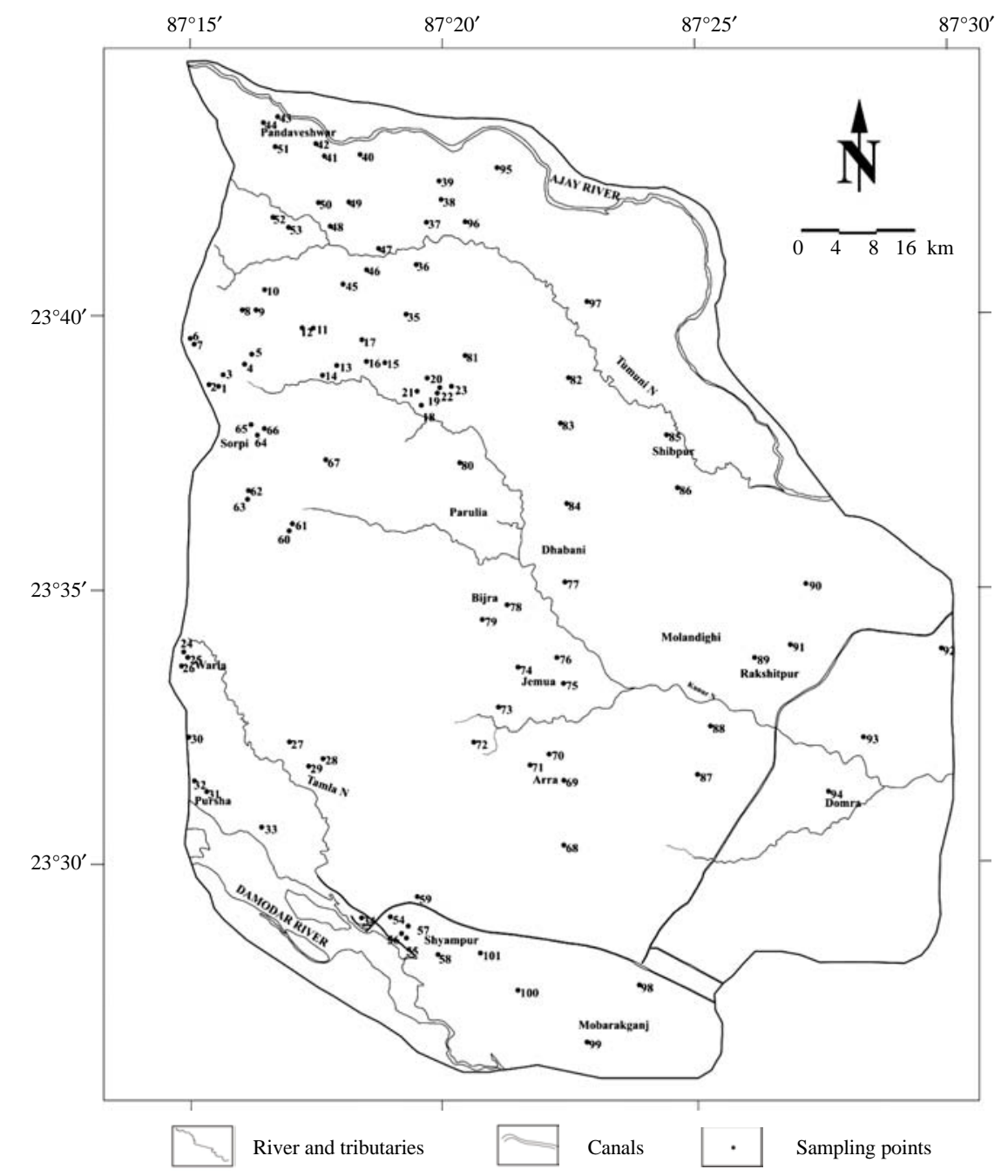

Fig. 1: Study area 
The quaternary alluvial fill tends to thicken towards East and Southeast. Towards West, it thins out on Tertiary Gondwana terrain. In the study area, aquifer ranges in thickness from 20-120 m (Central Ground Water Board, 2006). As the alluvium thickness increases towards East, a number of intervening structures within alluvial aquifer are present. This results in a complex nature of hydrogeology which leads to formation of many temporary aquifer systems in the region. Few deeper aquifers in the Eastern side of the area occur under confined condition whereas in most of the areas aquifers occur under unconfined to Semiconfined State. The climate of the area is semi arid. It is characterized by a hot and dry Summer followed by the monsoon rains from June to September and a cool pleasant Winter.

Lithology: Two broad types of lithologies are found within the study area. Around Western part of the study area, coarse to moderate grained sandstone, shale and laterite occur. In the West, coarse gritty soil blended with rock fragments is formed from the weathering of pegmatite's quartz, conglomeratic sandstone, weathered granitic rocks and sandstone (ADDA, 2006). Towards the eastern side, the lithotype comprises mostly of clay, shale and argillaceous limestone which overlie the granular zone. The clay beds are associated with the tertiary sediments. These sediments are of two types, first, lithomergic clays associated with laterites and second, white clays associated with Durgapur beds (http://wbenvironment.nic.in/status $7 . \mathrm{htm}$ ).

Groundwater condition of the study area: Geological control of the occurrence of groundwater indicates that groundwater in area occurs generally under unconfined to semiconfined state. Continuous sequence of sand and gravel facilitate infiltration of rainfall to the groundwater body. Water table in post monsoon season lies at a depth of 60-120 m while water table depth in premonsoon season ranges between $50-90 \mathrm{~m}$ from mean sea level. This considerable seasonal fluctuation of water table is the result of combined effect of evapotranspiration and discharge of groundwater by outflow and artificial draft. Groundwater contour maps of premonsoon (Fig. 2) and post monsoon season (Fig. 3) (where along $\mathrm{x}$-axis and

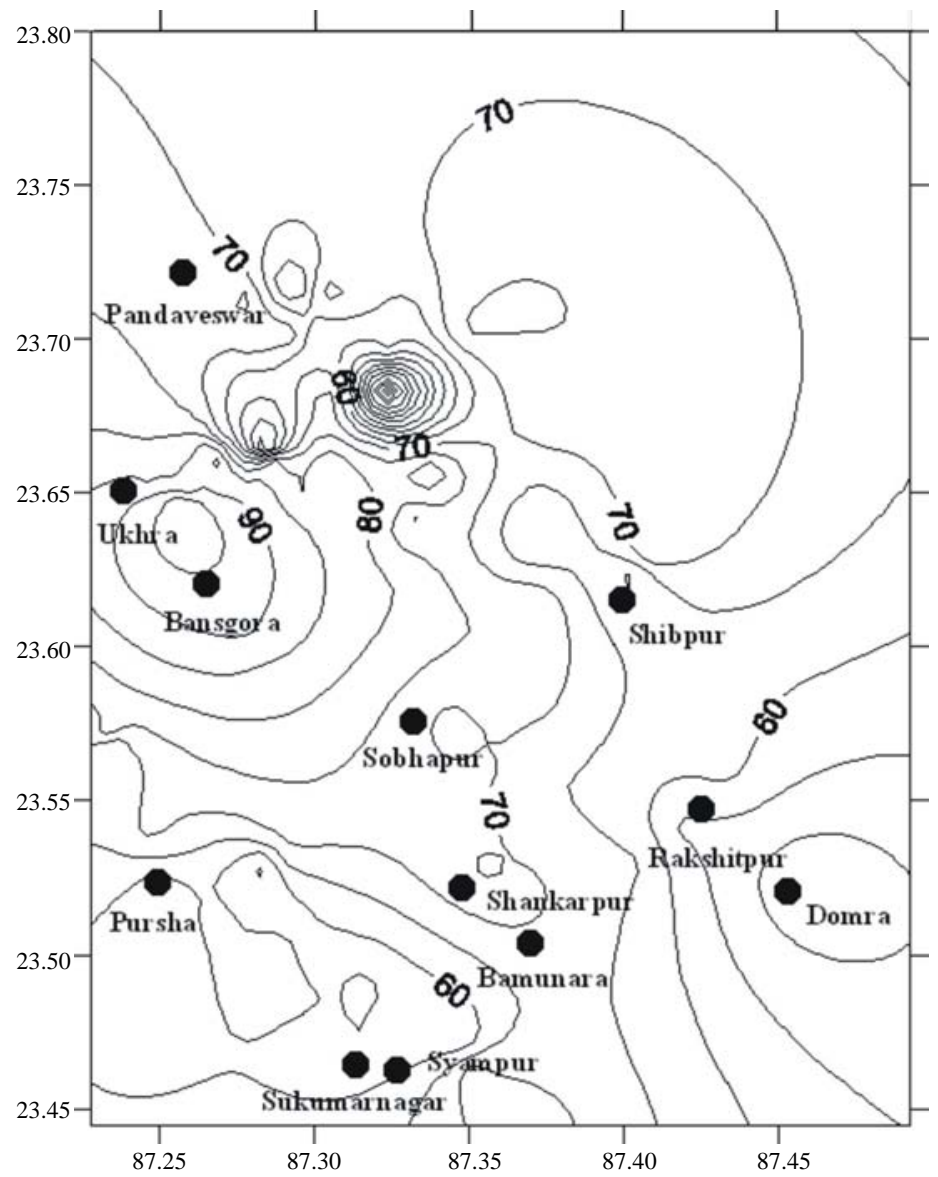

Fig. 2: Water table contour map of premonsoon season 


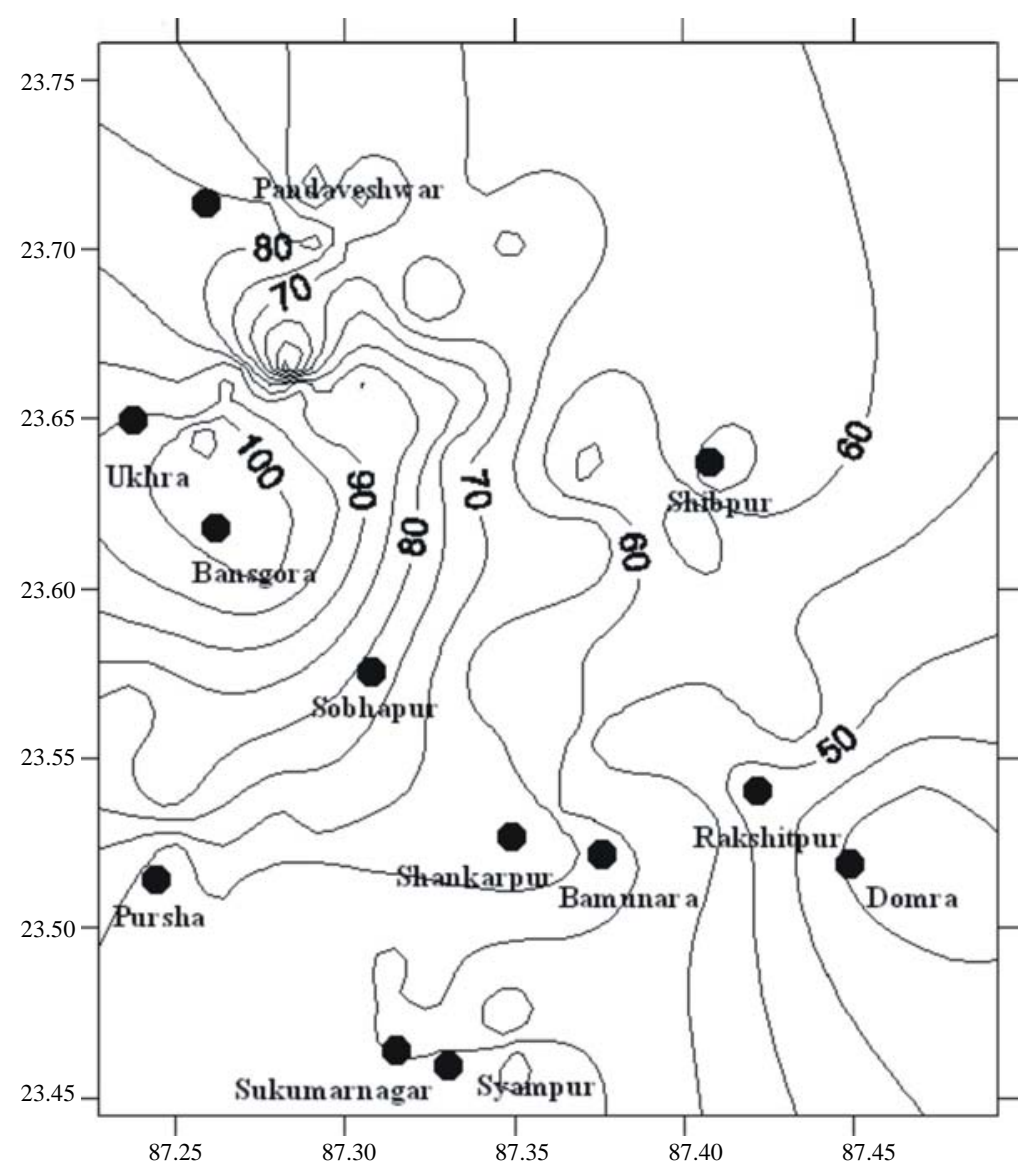

Fig. 3: Water table contour map of postmonsoon season

$\mathrm{y}$-axis, longitude and latitudes are plotted, respectively in degrees) show the flow pattern of the area. The contours are shown in meters. There is no marked difference in the flow pattern between premonsoon and postmonsoon season (Fig. 2 and 3). Regional flow of groundwater is towards Southeast. Water table contour maps suggest greater permeability of the Eastern part in comparison to the Western part of the study area. In the postmonsoon season water table almost reached the surface in the Eastern part and Southwestern part. A groundwater high near Ukhra in the Western part is envisaged. In premonsoon season a groundwater depression with steep gradient (Fig. 2) is noticed in the Southeast of Pandaveshwar of Northern part of the study area.

\section{MATERIALS AND METHODS}

About 99 and 119 number of groundwater samples from were collected in premonsoon and postmonsoon season, respectively from different locations of the study area. Electrical conductivity and $\mathrm{pH}$ of the samples were measured within $4 \mathrm{~h}$ of sample collection. The parameters like chloride, nitrate, potassium, sodium, magnesium, calcium, sulphate and bicarbonate were analysed. Analysis of samples has been done according to standard methods adopted by APHA. The $\mathrm{pH}$ and $\mathrm{EC}$ were measured by means of $\mathrm{pH}$ meter (EUTECH $\mathrm{pH} 1100$ ) and conductivity meter (EUTECH Con 510), respectively. TDS were computed from EC multiplied by a factor (0.55-0.75), depending on relative concentrations of ions. $\mathrm{Na}^{+}$and $\mathrm{K}^{+}$were determined by flame photometer (TECHCOMP UV-2300). $\mathrm{NO}_{3}{ }^{-}$and $\mathrm{SO}_{4}{ }^{2-}$ were analyzed by spectrophotometer. $\mathrm{TH}$ and $\mathrm{TA}$ as $\mathrm{CaCO}_{3}, \mathrm{Ca}^{2+}, \mathrm{HCO}_{3}^{-}$ and $\mathrm{Cl}^{-}$were analysed by titrimetric method. $\mathrm{Mg}^{2+}$ was calculated from $\mathrm{TH}$ and $\mathrm{Ca}^{2+}$ contents. The ion-balanceerror computation, taking the relationship between the total cations $\left(\mathrm{Ca}^{2+}, \mathrm{Mg}^{+2}, \mathrm{Na}^{+}, \mathrm{K}^{+}\right.$and $\left.\mathrm{Fe}^{2+}\right)$ and the total anions $\left(\mathrm{PO}_{4}{ }^{3+}, \mathrm{NO}_{3}{ }^{-}, \mathrm{SO}_{4}{ }^{2-}, \mathrm{CO}_{3}{ }^{2-}, \mathrm{HCO}_{3}{ }^{-}\right.$and $\left.\mathrm{Cl}^{-}\right)$for each set of complete analyses of water sample is observed to be within the range of acceptability $( \pm 5 \%)$ used in most laboratories (Domenico and Schwartz, 1990).

\section{RESULTS AND DISCUSSION}

Chemical constituents that affect the suitability of water for irrigation are total concentration of soluble salts 
(broadly related to the electrical conductivity of water), relative proportion of sodium to calcium and magnesium (SAR), relative proportion of bicarbonate to calcium and magnesium (RSC) (Karanth, 1997). Electrical conductivity determines the Salinity hazard. Water with high $\mathrm{Na}^{+}$and low in $\mathrm{Ca}^{2+}$ may enrich the soil with $\mathrm{Na}^{+}$by ion exchange which destroys the soil structure due to dispersion of clay particles. Higher salinity causes lower osmotic activity of plants (Subramani et al., 2005). The classification of groundwater based on salinity hazard as per US Salinity Lab (USSL) for irrigation purpose (Table 1) reveals that only $5 \%$ of the premonsoon samples and $7 \%$ of postmonsoon samples are unsuitable for irrigation.

According to the electrical conductivity values water quality in the study area is mostly in good to doubtful category for irrigation. Dissolved salt increases the osmotic potential of soil water and an increase in osmotic pressure of the soil solution increases the amount of energy which plants must expend to take up water from soil. As osmotic pressure increases, respiration increases and growth of most plants decline progressively (www.fao.org/docrep/tossle 03, htm). High salt content by means of high electrical conductance in water leads to formation of saline soil and high sodium content by means of high Sodium Adsorption Ratio (SAR) produce an alkaline soil (Ragunath, 2006). Alkali soil having unfavourable structure, peddles easily and restricts the aeration. Increase of sodium concentration deteriorates soil properties by reducing permeability (Kelley, 1951; Tijani, 1994). 11SAR is estimated by the equation:

$$
\text { Sodium Adsorption Ratio (SAR) }=\frac{\mathrm{Na}}{\sqrt{\mathrm{Ca}+\mathrm{Mg} / 2}}
$$

where, all ionic concentrations are expressed in epm. According to the US Salinity Laboratory classification for irrigation water based on SAR values, almost $98 \%$ of premonsoon samples of the study area are of excellent type (Table 2). Relative proportion of sodium to calcium and magnesium can be determined by means of percent sodium which can be calculated by the equation:

$$
\mathrm{Na}(\%)=\left[\left(\mathrm{Na}^{+}\right)+\left(\mathrm{K}^{+}\right)\right] \times 100 /\left(\mathrm{Ca}^{2+}+\mathrm{Mg}^{2+}+\mathrm{Na}^{+}+\mathrm{K}^{+}\right)
$$

where, all ionic concentrations are expressed in epm. The classification of groundwater samples in terms of percent sodium (Table 3 ) exhibits that almost $83.2 \%$ postmonsoon samples fall under good to permissible category whereas almost $62.5 \%$ premonsoon samples fall under permissible to doubtful category. In irrigation water, sodium increases the dispersion of colloids of clays when it comes in contact with soil and displaces the divalent
Table 1: Salinity hazard classes based on USSL classification

\begin{tabular}{lllcc}
\hline $\begin{array}{l}\text { Salinity } \\
\text { hazard class }\end{array}$ & $\begin{array}{l}\text { EC in } \\
\text { micro-mhos } \\
\text { per cm }\end{array}$ & $\begin{array}{l}\text { Remark on } \\
\text { quality }\end{array}$ & $\begin{array}{c}\text { Numbers of } \\
\text { pre-monsoon } \\
\text { samples }\end{array}$ & $\begin{array}{c}\text { Numbers of } \\
\text { post-monsoon } \\
\text { samples }\end{array}$ \\
\hline C1 & $100-250$ & Excellent & 11 & 13 \\
C2 & $250-750$ & Good & 31 & 31 \\
C3 & $750-2250$ & Doubtful & 52 & 68 \\
C4 and C5 & $>2250$ & Unsuitable & 5 & 7 \\
\hline
\end{tabular}

Table 2: Sodium hazard classes based on USSL classification

\begin{tabular}{lclcc}
\hline $\begin{array}{l}\text { Sodium } \\
\text { hazard class }\end{array}$ & $\begin{array}{c}\text { SAR in } \\
\text { equivalents } \\
\text { per mole }\end{array}$ & $\begin{array}{l}\text { Remark } \\
\text { on quality }\end{array}$ & $\begin{array}{c}\text { Numbers of } \\
\text { pre-monsoon } \\
\text { samples }\end{array}$ & $\begin{array}{c}\text { Numbers of } \\
\text { post-monsoon } \\
\text { samples }\end{array}$ \\
\hline S1 & 10 & Excellent & 97 & 119 \\
S2 & $10-18$ & Good & 2 & Nil \\
S3 & $18-26$ & Doubtful & Nil & Nil \\
S4 and S5 & $>26$ & Unsuitable & Nil & Nil \\
\hline
\end{tabular}

Table 3: Sodium percent water class

\begin{tabular}{llcc} 
Sodium (\%) & Water class & Pre-monsoon samples & $\begin{array}{c}\text { Post-monsoon } \\
\text { samples }\end{array}$ \\
\hline$<20$ & Excellent & 2 & 17 \\
$20-40$ & Good & 28 & 63 \\
$40-60$ & Permissible & 40 & 36 \\
$60-80$ & Doubtfull & 22 & 03 \\
$>80$ & Unsuitable & 7 & Nil \\
\hline
\end{tabular}

cations $\mathrm{Ca}^{2+}$ and $\mathrm{Mg}^{2+}$. This has a negative effect on the structure of the soil and reduces its capacity to conduct water and air through its profile. As a consequence of which the damage in soil fertility takes place.

Excess of calcium and magnesium brings higher carbonate and bicarbonate which leads to much greater alkali formation. The greater alkali formation is indicated by SAR and RSC which effects agriculture unfavorably (Eaton, 1950; Richards, 1954). RSC values of the groundwater of the present area suggest that almost $88 \%$ of premonsoon samples and $80.87 \%$ of postmonsoon samples represent good quality as water having $<1.25 \mathrm{epm}$ of RSC.

Groundwater quality index for irrigation: Assessment of groundwater quality index with respect to different uses and purposes has been carried out by several workers around the world. Stigter et al. $(2006 \mathrm{a}, \mathrm{b})$ used groundwater quality indices for evaluating influence of agriculture activities on several key parameters of groundwater chemistry and potability. Saeedi et al. (2010) used the groundwater quality index to identify the places with best drinking water quality in the Qazvin province, West Central of Iran. Sharma and Patel (2010) used the Water Quality Index (WQI) Method to determine the pollution potential of groundwater of Surat city, India. Reza and Singh (2010) used the technique to evaluate the potability of groundwater in Angul-Talcher area, Orissa, India. Ramakrishnaiah et al. (2009) used the tool to assess the suitability of groundwater of Tumkur, Karnataka, India for human consumption. Each of the 
essential parameters considered for irrigation water quality like EC, SAR, RSC show variation in the study area. Though, each of these parameters indicates that most of the samples fall under excellent to good category of water for irrigation, location wise water categories differ when judged on the basis of any one parameter. No single parameter is sufficient for classification of water for suitability to irrigation. Each of these parameters has its own significance on quality of water. Classification on the basis of any individual parameter cannot properly explain the suitability of the sample as a representative of whole water chemistry in terms of irrigation. Instead of using a number of classifications on the basis of individual parameters one significant classification scheme based on combination of relative importance of essential parameters with respect to irrigation potential will be worthy in decision making.

The classification scheme, presented in this study, has been devised on the basis of relative importance of the most significant irrigation water quality parametersSAR, EC and RSC. The whole Water Quality Indexing System (WQI) were carried out through three steps.

In the first step, each of the three parameters is assigned a weight according to their relative importance in irrigation purpose. Assigning weight to individual parameters, keeping the order of importance or priority of parameters ( $\mathrm{SAR}>\mathrm{EC}>\mathrm{RSC}$ ) intact is based on knowledge and experience of the individual. SAR is assigned a weight of 5 as it is directly related to sodium proportion among the other cations and signify maximum importance for irrigation purpose. EC is considered as second important parameter for irrigation and is assigned a weight of 3 as it suggests salinity hazard. RSC is signified as third important parameter and assigned a weight of 2 as it predicts the accumulation of sodium in the soil based on the potential precipitation of calcium and magnesium carbonate. Relative Weight (W) of individual parameter is determined. For SAR it is calculated as $\mathrm{W}_{\mathrm{SAR}}=5 /(5+3+2)$, i.e., $0.5 ; \mathrm{W}_{\mathrm{EC}}=0.3$ and $\mathrm{W}_{\mathrm{RSC}}=0.2$.

Second step computes the relative Weight $\left(\mathrm{W}_{\mathrm{i}}\right)$ of individual parameter where weight of individual parameters $\left(\mathrm{w}_{\mathrm{i}}\right)$ is divided by the summation of weight of all the parameters $(n)$ involved:

$$
\mathrm{W}_{\mathrm{i}}=\mathrm{w}_{\mathrm{i}} / \sum_{\mathrm{i}=1}^{\mathrm{n}} \mathrm{w}_{\mathrm{i}}
$$

In the third step a quality rating $\left(Q_{i}\right)$ for each parameter is determined in the following manner:

$$
\mathrm{Q}_{\mathrm{i}}=\left(\mathrm{C}_{\mathrm{i}} / \mathrm{S}_{\mathrm{i}}\right) \times 100
$$

Where:

$Q_{i}=$ The quality rating of individual parameter

$\mathrm{C}_{\mathrm{i}}=$ The concentration of individual parameter in each water sample

$\mathrm{S}_{\mathrm{i}}=$ The standard concentration value for irrigation quality of the individual parameter

In this study the standard values of individual parameters have been taken from mean values of doubtful category of USSL classification of water for irrigation purpose (Table 1 and 2). For final computation of GWQI, Subindex (SI) of individual parameter of each water sample is worked out using the relationship:

$$
\mathrm{SI}_{\mathrm{i}}=\mathrm{W}_{\mathrm{i}} \times \mathrm{Q}_{\mathrm{i}}
$$

In this study the subindex of parameters are $\mathrm{SI}_{\mathrm{SAR}}$, $\mathrm{SI}_{\mathrm{EC}}$ and $\mathrm{SI}_{\mathrm{RSC}}$. Finally, the GroundWater Quality Index of each water sample is determined as:

$$
\mathrm{GWQI}_{\mathrm{i}}=\Sigma\left(\mathrm{SI}_{\mathrm{SAR}}\right)_{\mathrm{i}}+\left(\mathrm{SI}_{\mathrm{EC}}\right)_{i}+\left(\mathrm{SI}_{\mathrm{RSC}}\right)_{i}
$$

This process transforms the concentrations of all parameters of individual water samples into a unitless number which may be termed as quality score for irrigation use of that sample of groundwater. The derived quality scores or index values have been grouped into four classes based on the quality score or index values of individual samples the sampling locations have been contoured to generate ISO Index maps of both premonsoon (Fig. 4) and postmonsoon (Fig. 5) seasons (where along $\mathrm{x}$ and $\mathrm{y}$ axis, longitude and latitudes are plotted, respectively in degrees). These figures show most of the samples $(87.8 \%$ in premonsoon and $84.02 \%$ of postmonsoon season) are grouped under excellent to good category. About $9 \%$ of premonsoon samples and $12 \%$ of postmonsoon samples belong to doubtful class.

Only $3 \%$ of samples in both pre and postmonsoon seasons are of unsuitable category. It has been observed from the ISO Index maps that none of the locations fall under doubtful to unsuitable category in both premonsoon and postmonsoon seasons rendering the area suitable for irrigation at least in one season. The areas like Pursha, Bansgora, fall under doubtful to unsuitable category in premonsoon whereas areas like Domra, Rakshitpur, Shibpur, Shankarpur belong to the doubtful category in postmonsoon season. Characteristically all of these areas are agriculture intensive zones with close proximity to industrial activities. Very less seasonal fluctuation of water table 
Environ.Res.J., 6 (3): 197-205, 2012

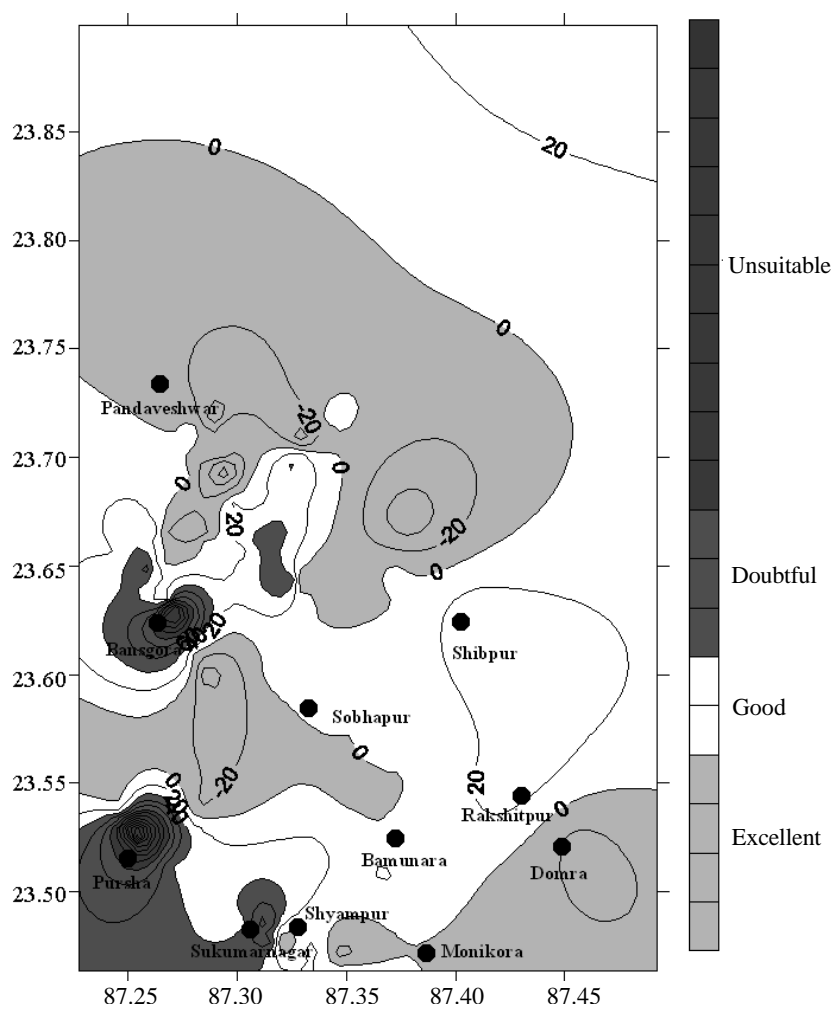

Fig. 4: ISO Index map of the study area in premonsoon season

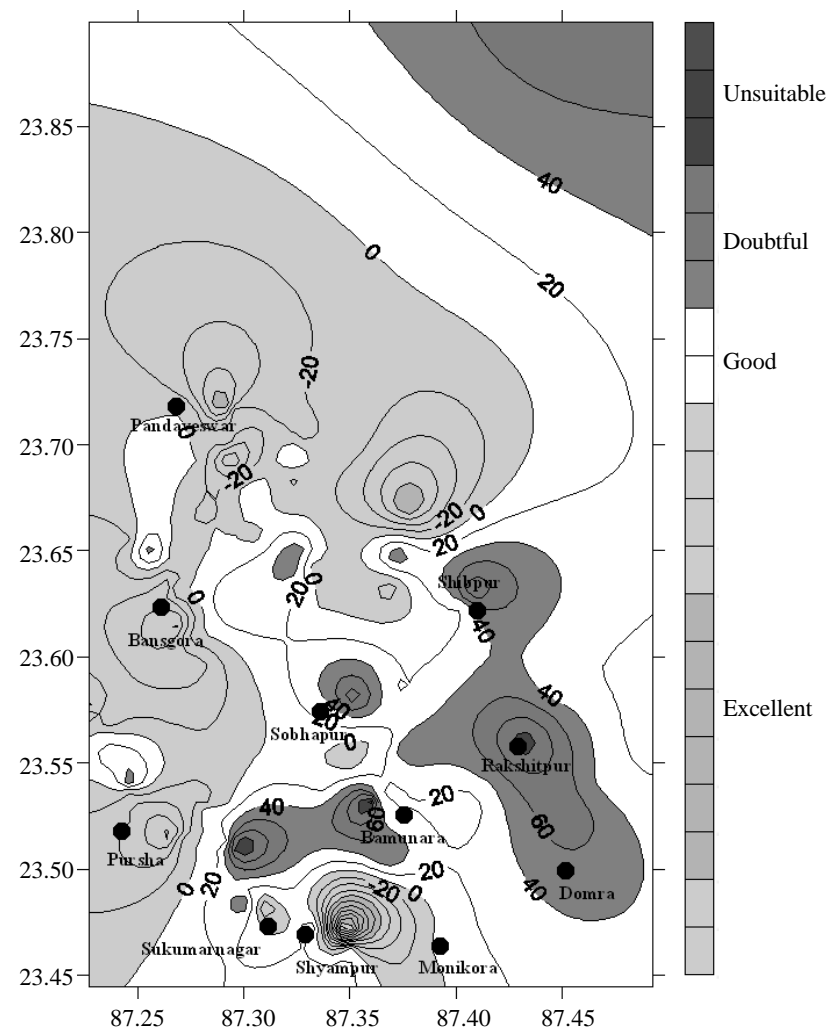

Fig. 5: ISO Index map in postmonsoon season 
Environ.Res. J., 6 (3): 197-205, 2012

Table 4: Seasonal variation of parameters

\begin{tabular}{|c|c|c|c|c|c|c|c|c|}
\hline \multirow[b]{2}{*}{ Locations } & \multicolumn{2}{|c|}{ DTW (m) } & \multicolumn{2}{|c|}{$\mathrm{EC}$ (micro-mhos per $\mathrm{cm}$ ) } & \multicolumn{2}{|c|}{ RSC (epm) } & \multicolumn{2}{|c|}{ SAR (epm) } \\
\hline & Pre & Post & Pre & Post & Pre & Post & Pre & Post \\
\hline Pursha & 2.30 & 2.13 & 1342 & 1985 & 10.07 & -9.65 & 5.85 & 0.910 \\
\hline Sukumarnagar & 3.66 & 3.13 & 842 & 605 & 1.76 & -2.07 & 15.34 & 0.876 \\
\hline Bansgora & 2.64 & 2.42 & 1432 & 2180 & 18.42 & -11.29 & 4.26 & 1.530 \\
\hline Domra & 4.11 & 2.49 & 2340 & 3330 & -7.39 & 0.50 & 1.28 & 1.180 \\
\hline Rakshitpur & 4.68 & 3.27 & 1614 & 1922 & -0.05 & 7.00 & 1.70 & 1.720 \\
\hline Shibpur & 5.25 & 4.32 & 951 & 1092 & 1.03 & 7.42 & 0.77 & 0.630 \\
\hline Shankarpur & 6.50 & 4.79 & 1363 & 1682 & -2.44 & 9.61 & 1.95 & 1.710 \\
\hline
\end{tabular}

(Table 4) suggests that the areas like Pursha, Sukumarnagar and Bansgora are groundwater discharge zones (most of the flow components of groundwater follow the regional trend, i.e, towards South and South East) and accumulates carbonate, bicarbonate and sodium in a large proportion in these zones which during postmonsoon season become diluted. Water table contour maps and seasonal fluctuation of water table suggest that the areas like Rakshitpur, Shibpur, Shankarpur possess near surface higher permeable aquifers and groundwater recharge areas. During monsoon greater amount of salts from surface and zone of aeration get dissolved in the percolating solution and contribute to the zone of saturation. Higher amount of EC and RSC put the groundwater in doubtful to unsuitable category of these areas. Industrial effluents, huge dewatering of deeper aquifes (usually contains high TDS) and its surficial discharge in CBM exploration may play a role in deteriorating groundwater quality of this region. Keeping in consideration the quantum of industries in the study area, particularly coal based power plants and steel industries the fly ashes and other dusts, released through chimneys may indirectly contaminate groundwater.

\section{CONCLUSION}

Instead of separate use of various parameters in determining irrigation potential of groundwater of an area use of GWQI technique, applied in this study is the better option in decision making. The technique involves three most important parameters- SAR, EC and RSC of irrigation water quality in computing the indices or quality scores. ISO Index maps based on indices clearly demonstrate without ambiguity the irrigation potential of water of an area. In the present case study ISO Index maps show seasonal variation of water qualities in terms of irrigation in few locations of Southeastern and Southwestern part of the study area. The higher concentrations of carbonate, bicarbonate and sodium ions increase the values of RSC and SAR in the areas of Southwestern part in premonsoon and put it under doubtful to unsuitable category but in the postmonsoon these areas fall under good to excellent category. The areas in the Southeastern part show good to excellent category in the premonsoon and doubtful to unsuitable category in the postmonsoon season. Hydrogeologically the areas of concern in the southwestern part and Southeastern parts belong to groundwater discharge zones and groundwater recharge zones, respectively. These discharge and recharge zones are correlatable with the seasonal accumulation of carbonate, bicarbonate, sodium ions in premonsoon and TDS (including high carbonate and bicarbonate) in postmonsoon seasons, respectively.

\section{REFERENCES}

ADDA, 2006. Perspective plan for asansol durgapur planning area. Asansol Durgapur Development Authority Status Report, January 2006, pp: 2.

Ahmed, I. and R. Umar, 2009. Groundwater flow modelling of Yamuna-Krishniinterstream, a part of central Ganga Plain Uttar Pradesh. J. Earth Syst. Sci., 118: 507-523.

Central Ground Water Board, 2006. Dynamic ground water resources of India. Ministry of Water Resources, Government of India, India, pp: 126.

Doll, P., 2009. Vulnerability to the impact of climate change on renewable groundwater resources: A global-scale assessment. Environ. Res. Lett., Vol. 4. 10.1088/1748-9326/4/3/035006.

Domenico, P.A. and F.W. Schwartz, 1990. Physical and Chemical Hydrology. John Wiley and Sons, New York.

Eaton, F.M., 1950. Significance of carbonates in irrigation water. Soil Sci., 69: 123-133.

FAO, 2010. FAO: AQUASTAT-FAO's global information system on water and agriculture. Food and Agriculture Organization of the United Nations, Rome, Italy.

Foster, S. and D.P. Loucks, 2006. Non-Renewable Groundwater Resources: A Guidebook on SociallySustainable Management for Water-Policy Makers. UNESCO, Paris, France. 
Guzman-Soria, E., J. Hernandez-Martinez, J.A. GarciaSalazar, S. Rebollar-Rebollar, M.T. De La GarzaCarranza and D. Hernandez-Soto, 2009. Groundwater consumption in guanajuato, Mexico. Agrociencia, 43: 749-761.

Handa, B.K., 1964. Modified classification procedure for rating irrigation waters. Soil Sci., 98: 264-269.

Handa, B.K., 1965. Modified Hill-piper diagram for presentation of water analysis data. Curr. Sci., 34: 131-314.

Hem, J.D., 1985. Study and Interpretation of the Chemical Characteristics of Natural Water. 3rd Edn., U.S. Government, Washington, DC, USA., pp: 117-120.

IWMI, 2005. Water policy briefing. IWMI International Water Management Institute, Tata Water Policy Program Report, pp: 3.

Karanth, K.R., 1997. Groundwater Assessment, Development and Management. Tata McGraw-Hill, New Delhi, India, Pages: 250.

Karmegam, U., S. Chidamabram, P. Sasidhar, R. Manivannan, S. Manikandan and P. Anandhan, 2010. Geochemical characterization of groundwater's of shallow coastal aquifer in and around Kalpakkam, South India. Res. J. Environ. Earth Sci., 2: 170-177.

Kelley, W.P., 1951. Alkali, Soils, their Formation, Properties and Reclamation. Reinhold Pub., New York, USA.

MoA-GoI, 2003. All India report on agricultural census, 2001-2002. Ministry of Agriculture, Government of India, New Delhi, India.

Ragunath, H.M., 2006. Groundwater. Wiley Eastern Limited, New Delhi, India, Pages: 301.

Ramakrishnaiah, C.R., C. Sadashivaiah and G. Ranganna, 2009. Assessment of water quality index for the groundwater in Tumkur Taluk, Karnataka State, India. E-J. Chem., 6: 523-530.

Reza, R. and G. Singh, 2010. Assessment of ground water quality status by using water quality index method in orissa, India. World Applied Sci. J., 9: 1392-1397.

Richards, L.A., 1954. Diagnosis and Improvement of Saline and Alkali Soils. 1st Edn., United States Department of Agriculture, Washington, DC., USA.

Saeedi, M., O. Abessi, F. Sharifi and H. Meraji, 2010. Development of groundwater quality index. Environ. Monit. Assess, 163: 327-335.
Scanlon, B.R., I. Jolly, M. Sophocleous and L. Zhang, 2007. Global impacts of conversions from natural to agricultural ecosystems on water resources: Quantity versus quality. Water Resour. Res., Vol. 43. 10.1029/2006WR005486.

Scott, C.A. and B. Sharma, 2009. Energy supply and the expansion of groundwater irrigation in the indusganges basin. Int. J. River Basin Manage., 7: 1-6.

Shah, T., J. Burke and K. Villholth, 2007. Groundwater: A Global Assessment of Scale and Significance. In: Water for Food, Water for Life, Molden, D., (Ed.). IWMI, London, pp: 395-423.

Sharma, N.D. and J.N. Patel, 2010. Evaluation of groundewater quality index of the urban segments of Surat City, India. Int. J. Geol., Vol. 4.

Shiklomanov, I.A., 2000. Appraisal and assessment of world water resources. Water Int., 25: 11-32.

Stigter, T. Y., L. Ribeiro and A.M.M. Carvalho Dill, $2006 \mathrm{~b}$. Application of a groundwater quality index as an assessment and communication tool in agroenvironmental policies -Two Portuguese case studies. J. Hydrol., 327: 578-591.

Stigter, T.Y., L. Ribeiro and A.M.M. Carvalho Dill, 2006a. Evaluation of an intrinsic and a specific vulnerability assessment method in comparison with groundwater salinisation and nitrate contamination levels in two agricultural regions in the south of Portugal. J. Hydrogeol., 14: 79-99.

Subramani, T., L. Elango and S.R. Damodarasamy, 2005. Groundwater quality and its suitability for drinking and agricultural use in Chithar River Basin, Tamil Nadu, India. Environ. Geol., 47: 1099-1110.

Tijani, M.N., 1994. Hydrochemical assessment of groundwater in Moro area, Kwara State, Nigeria. Environ. Geol., 12: 194-202.

Wang, J., J. Huang, S. Rozelle, Q. Huang and L. Zhang, 2009. Understanding the water crisis in Northern China: What the government and farmers are doing. Int. J. Water Resour. Dev., 25: 141-158.

Zekster, I.S. and L.G. Everett, 2004. Groundwater Resources of the World and their use. IHP-VI Series on Groundwater No. 6. United Nations Educational, Scientific and Cultural Organization, Paris, France, ISBN-13: 92-9220-007-0, pp: 1-342. 